\title{
Radiographic analysis the obturation's quality in root canal treatment performed by a South Brazilian sample of undergraduate students
}

\author{
Análise radiográfica da obturação em tratamentos endodônticos \\ realizados por alunos de Odontologia de \\ uma amostra do sul do Brasil
}

Dayane Machado RIBEIRO' ${ }^{1}$ 0000-0002-9177-3863

Marcela Daniela HENCKEL ${ }^{2}$

Fernanda Weber MELLO' ${ }^{1}$ (DD 0000-0002-2566-268X

Mara Cristina Santos FELIPPE ${ }^{1}$

Wilson Tadeu FELIPPE ${ }^{1}$

\section{ABSTRACT}

Objective: to investigate the quality of root canal treatments performed by undergraduate students. Methods: 274 root-filled teeth (excluding molars) from the Department of Endodontology of the Federal University of Santa Catarina in a nine-year period were selected and evaluated by two calibrated examiners. The evaluation was based on tooth type, number of root canals, presence or absence curvature, length of filling material considered the radiographic apex as reference (considered adequate shorter than $2 \mathrm{~mm}$ from radiographic apex), filling material density, filling taper, and overall quality of RCT. Chi-square and Fisher exact tests were performed to analyze associations between variables of interest $(p<0.05)$. Results: 197 RCT were classified as acceptable $(71.9 \%)$. The frequency of adequate RCT was significantly higher in incisor $(79.4 \%)$ than in premolars (66.4\%) or canines $(58.1 \%)(p=0.015)$. The number of canals did not influence root canal quality in this sample ( $p>0.05)$. The factor more frequently identified as unacceptable was filling length (26.6\%). All RCT performed in curved teeth and classified as unacceptable were underfilled. Procedural errors, such as perforations or instrumental separation, were not found in this sample. Conclusion: The most common criteria identified as unacceptable was the length of the filling material. Incisors had better quality assessment rates than canines and premolars. The highquality rates found in this sample may be linked to the professor/student rates.

Indexing terms: Dental students. Root canal treatment. Technical expertise.

\section{RESUMO}

Objetivo: Investigar a qualidade dos tratamentos endodônticos realizados por alunos de graduação em odontologia. Métodos: 274 dentes (excluindo molares) com endodontia realizada no Departamento de Endodontia da Universidade Federal de Santa Cataria

$\boldsymbol{\nabla} \boldsymbol{\nabla} \nabla \boldsymbol{\nabla}$

1 Universidade Federal de Santa Catarina, Centro de Ciências da Saúde, Departamento de Odontologia. Campus Universitário, Trindade, 88040-900, Florianópolis, SC, Brasil. Correspondência para / Correspondence to: DM RIBEIRO. E-mail: <dayanemribeiro@yahoo.com.br>.

2 Centro Odontológico Carlos Bier. Florianópolis, SC Brasil.

$\checkmark \nabla \mathbf{v}$

How to cite this article

Ribeiro DM, Henckel MD, Mello FW, Felippe MCS, Felippe WT. Radiographic analysis the obturation's quality in root canal treatment performed by a South Brazilian sample of undergraduate students. RGO, Rev Gaúch Odontol. 2019;67:e20190040. http://dx.doi.org/10.1590/1981863720190004020180038 
durante 9 anos foram avaliados por dois examinadores calibrados. A avaliação foi baseada no tipo de dente, número de condutos radiculares, presença ou ausência de curvatura, nível da obturação em relação ao ápice radiográfico (considerado adequado quando a menos de $2 \mathrm{~mm}$ do ápice radiográfico), densidade do material obturador, espessura da obturação e qualidade geral do tratamento. Teste qui quadrado e exato de Fisher foram usados para avaliar a associação entre as variáveis de interesse (p<0.05). Resultados: 197 tratamentos foram considerados adequados (71.9\%). A frequência de tratamentos adequado foi maior em incisivos (79.4\%), do que em pré-molares (66.4\%) e caninos (58.1\%) ( $p=0.015)$. O número de canais não influenciou a qualidade do tratamento nessa amostra (p>0.05). O fator mais associado a tratamentos com qualidade inadequada foi o nível da obturação (26.6\%). Todos os tratamentos inadequados, em dentes com curvatura, estavam com obturação mais do que $2 \mathrm{~mm}$ aquém do ápice. Não houveram erros, como perfuração ou separação de instrumentais. Conclusão: O critério mais frequentemente identificado como inadequado foi o nível apical da obturação. Tratamentos realizados em incisivos resultaram em qualidade superior aos em caninos e pré-molares. A alta qualidade dos tratamentos dessa amostra pode estar relacionada com a razão estudante/professor.

Termos de indexação: Estudantes de Odontologia. Endodontia. Competência profissional.

\section{INTRODUCTION}

Root canal treatment $(\mathrm{RCT})$ is a routine in general dental practice and is required in dentistry school as a part of undergraduate education. The overall aim of RCT is the elimination and prevention of bacterial contamination in the root canal system and periapical tissue. These goals are achieved by chemomechanical debridement and root canal sealing [1]. Root canal treatment quality can influence the final treatment outcome and, consequently, teeth survival rates. However, there is still not a defined criterion for assessing RCT quality [2]. Radiographically, an adequate RCT can be described with a proper taper, absence of procedural errors and root canal filling with adequate density and within $2 \mathrm{~mm}$ of the radiographic apex [3,4].

$\mathrm{RCT}$ is the foundation for further rehabilitation; therefore, it contributes decisively to the final prognosis of the tooth [5]. Considering the improvement in life expectancy, there is also an increased demand for RCT in the dental market. Thus, it is important that undergraduate students be provided with knowledge and sufficient experience to perform these conventional therapies before graduation [6]. Procedural errors can compromise the disinfection quality of RCT and, consequently, affect the treatment's outcome [7]. Post-treatment prevalence of disease seems to be positively associated with the root canal filling density and length [8].

Several studies aimed to describe the quality of RCT performed by undergraduate students [9-12]. These studies demonstrated that RCT quality is associated with preclinical and clinical activity workload, treatment protocols, professor supervision, professor/student rates, professional qualification, and mentor's dedication [13]. Accordantly to European guidelines, all dental students should be able to perform RCT in non-complicated single and multiple rooted teeth upon graduation. For this to happen, it essential that they learn first how to diagnose appropriately endodontics conditions, as well as, indications and contra-indications for RCT. This knowledge prevents unnecessary interventions, complications, and further demotivation by undergraduate dental students [14].

A systematic review recently published revealed that the quality of RCT performed using hand instrumentation by undergraduate students is low and decrease accordantly to tooth groups' difficulties [15]. Considering the technological advances that occurred in endodontology in the past years, and the new technologies yet to come, an education based on scientific evidence seem to be the best way to provide a high standard academic formation in dentistry schools. Therefore, this study aimed to audit the quality of RCTs performed by Brazilian undergraduate students, as well as to assess the main difficulties encountered by these students.

\section{METHODS}

\section{Approval of the ethics committee}

The Ethics Committee in Human Research of the Federal University of Santa Catarina (UFSC) approved this study by the number 449/09 302164. All data regarding patients' information remained confidential and was assessed only for study purpose.

\section{Root canal treatment procedures}

The sample was constituted by endodontically treated teeth, which had their treatment performed by 
undergraduate students of the UFSC dentistry school's sixth and seventh semesters, corresponding to students coursing the fourth year, and had initial and final periapical radiographs. A team of Ph.D. professors supervised all of the students performing endodontic treatments, and all procedures were performed by hand instrumentation. The overall professor/student ratio in the endodontic clinic is 1:10. However, students perform treatment in pairs; therefore, there is one professor for five concomitant RCTs performed. All treatments performed in the endodontic clinics follow the same protocol, with the length of the filling material adjusted to $1 \mathrm{~mm}$ shorter in relation to the radiographic apex and root canal filling performed by lateral condensation technique.

\section{Sample selection and quality assessment}

From the endodontic clinic archive, 304 endodontic threated teeth were randomly selected, from a nine-year period. From which 30 cases were excluded because of lack of information or radiographic exams in the file. Therefore, the sample consisted of 274 endodontic threated teeth (excluding molars due to the reduced number of treatments performed), from which 136 were incisor, 31 canines, and 107 premolars.

One previous calibrated examiner performed the assessment using periapical radiographic images. The calibration was conducted by an intra-examiner Cohen's kappa test, in which the agreement value was 0.8 (coefficients above 0.7 were considered as reliable). The quality assessment was carried out with indirect illumination provided by a negatoscope, assisted by a magnifier (2-fold increase) and a millimetric ruler. Anatomical characteristics and quality assessment criteria are available in table 1 . With regards to the taper of the filling material, this criterion was considered satisfactory when the shape was conical and respected the anatomical morphology of the root canal. The final quality of root canal filling was considered as satisfactory when all the criteria were graded as satisfactory.

Table 1. Clinical characteristics and examination criteria for root canal treatment quality assessment, Florianópolis (SC), 2018.

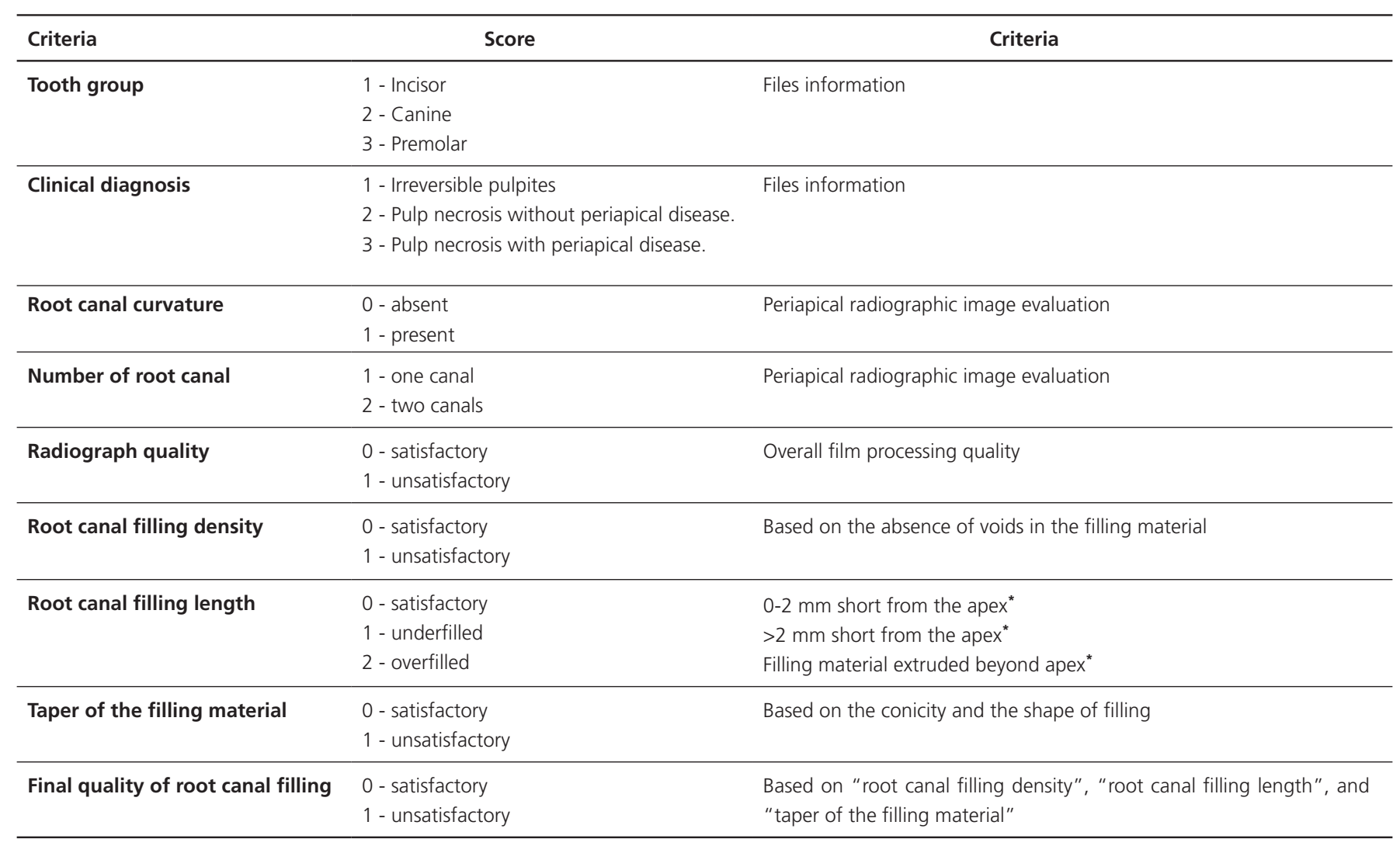

Note: *Radiographic apex. 


\section{Statistical analysis}

Data was tabulated on Excel 2016 (Microsoft Office 2016, Microsoft) and analyzed using statistical software SPSS Statistics 21 (IBM Corp., Armonk, NY, USA). Chi-square test and Fisher exact test were performed to investigate associations between variables of interest. The statistical significance was set at $\mathrm{a}=0.05$.

\section{RESULTS}

The majority of teeth was incisors, located in the upper jaw, single rooted and without root curvature. With regards to the clinical diagnosis of treated teeth, $50 \%$ were diagnosed with pulp necrosis associated with periapical radiolucency, $35 \%$ as irreversible pulpitis and $15 \%$ with pulp necrosis without periapical disease. Regarding radiographic quality, in all cases processed manually, $9.8 \%$ of the files presented inadequate processed radiographic images.

An association was found between tooth groups and overall quality of RCT $(p=0.015)$. Overall quality of RCT was found unsatisfactory in approximately $42 \%$ of canines, $34 \%$ of premolars and $21 \%$ of incisors. No statistical association was found between tooth group and individual quality assessment variables ( $p>0.05$ ). The overall filling density and taper of the filling material were considered satisfactory in more than $95 \%$ of cases independently of tooth groups. On the other hand, root canal filling level was more frequently assessed as unsatisfactory (underfilled or overfilled) than other criteria, especially in canines and premolars, which might have influenced the overall quality of the endodontic therapy (table 2).

In this study sample, 50 teeth had two root canals, from which all were premolars. Regarding RCT quality assessment, no statistical association was found between root canals number and quality criteria $(p>0.05)$. The larger number of canals present in premolars, especially upper first premolars, did not influence the quality of RCT performed by dental students in our sample (table 3).

Root curvature was present in 19 teeth, from which approximately 67\% were incisors and 33\% premolars. Curvatures were more frequently present in single-rooted

Table 2. Root canal quality criteria accordantly to teeth groups ( $n=274)$, Florianópolis (SC), 2018.

\begin{tabular}{|c|c|c|c|c|c|c|c|c|c|}
\hline \multirow{3}{*}{ Tooth group } & \multicolumn{9}{|c|}{ Quality assessment criteria* } \\
\hline & \multicolumn{2}{|c|}{ Filling density ${ }^{\mathbf{b}}$} & \multicolumn{3}{|c|}{ Filling length ${ }^{\mathbf{b}}$} & \multicolumn{2}{|c|}{ Filling taper ${ }^{\mathbf{b}}$} & \multicolumn{2}{|c|}{ Overall quality } \\
\hline & Satisfactory & Unsatisfactory & Satisfactory & Under & Over & Satisfactory & Unsatisfactory & Satisfactory & Unsatisfactory \\
\hline Incisor $(n=136)$ & 99.3 & 0.7 & 80.9 & 16.9 & 2.2 & 96.3 & 3.7 & 79.4 & 20.6 \\
\hline Canine $(n=31)$ & 100 & - & 61.3 & 35.5 & 3.2 & 96.8 & 3.2 & 58.1 & 41.9 \\
\hline Premolar $(n=107)$ & 98.1 & 1.9 & 67.3 & 30.8 & 1.9 & 96.3 & 3.7 & 66.4 & 33.6 \\
\hline
\end{tabular}

Note: "Values given as percentage, unless otherwise indicated. Under, underfilled; over, overfilled. ${ }^{\mathbf{a}}=p<0.05 ;{ }^{\mathbf{b}}=p>0.05$.

Table 3. Root canal quality criteria accordantly to number of root canals ( $n=274)$, Florianópolis (SC), 2018.

\begin{tabular}{|c|c|c|c|c|c|c|c|c|c|}
\hline \multirow{3}{*}{ Number of root canals } & \multicolumn{9}{|c|}{ Quality assessment criteria* } \\
\hline & \multicolumn{2}{|c|}{ Filling density ${ }^{\mathbf{b}}$} & \multicolumn{3}{|c|}{ Filling length ${ }^{\mathbf{b}}$} & \multicolumn{2}{|c|}{ Filling taper ${ }^{\mathbf{b}}$} & \multicolumn{2}{|c|}{ Overall quality ${ }^{\mathbf{b}}$} \\
\hline & Satisfactory & Unsatisfactory & Satisfactory & Under & Over & Satisfactory & Unsatisfactory & Satisfactory & Unsatisfactory \\
\hline One $(n=224)$ & 99.1 & 0.9 & 73.2 & 24.6 & 2.2 & 95.5 & 4.5 & 71.9 & 28.1 \\
\hline Two $(n=50)$ & 98 & 2 & 74 & 24 & 2 & 96 & 4 & 72 & 28 \\
\hline
\end{tabular}

Note: *Values given as percentage, unless otherwise indicated. Under, underfilled; over, overfilled. ${ }^{\mathbf{b}}=p>0.05$. 
teeth, and the clinical diagnosis more prevalent in these teeth was pulp necrosis associated with periapical disease. There was no statistical association between root canal curvature and quality assessment criteria ( $p>0.05$ ). However, all root canal fillings performed in curved roots and considered as unsatisfactory were underfilled (table 4).

Dental pulp necrosis was present among 65\% $(n=178)$ of analyzed teeth, in which $77 \%$ had periapical radiolucent lesion. A statistical association was found between clinical diagnosis and final RCT quality $(p=0.018)$. There was a higher prevalence of unsatisfactory RCT in teeth presenting pulp necrosis without periapical disease, and the only quality assessment criteria graded as unacceptable in this group of teeth was filling length, in which the majority was classified as underfilled. No association was found between clinical diagnosis and individual quality assessment criteria ( $p>0.05$ ).

The overall prevalence of unsatisfactory RCT in the sample was of $28.1 \%(n=77)$. The most common difficulty encounter by the students in RCTs was the length of the root canal filling in relation to the radiographic apex, assessed as unacceptable in $26.6 \%$ ( $n=73)$. Among these cases, $91.8 \%$

Table 4. Root canal quality criteria accordantly to root curvature ( $n=274)$, Florianópolis (SC), 2018.

\begin{tabular}{|c|c|c|c|c|c|c|c|c|c|}
\hline \multirow[b]{2}{*}{ Curvature } & \multicolumn{9}{|c|}{ Quality assessment criteria* } \\
\hline & \multicolumn{2}{|c|}{ Filling density ${ }^{\mathbf{b}}$} & \multicolumn{3}{|c|}{ Filling length ${ }^{\mathbf{b}}$} & \multicolumn{2}{|c|}{ Filling taper ${ }^{\mathbf{b}}$} & \multicolumn{2}{|c|}{ Overall quality } \\
\hline Present $(n=19)$ & 100 & - & 73.7 & 26.3 & - & 100 & - & 73.7 & 26.3 \\
\hline
\end{tabular}

*Values given as percentage, unless otherwise indicated. Under, underfilled; over, overfilled. ${ }^{\mathbf{b}}=p>0.05$

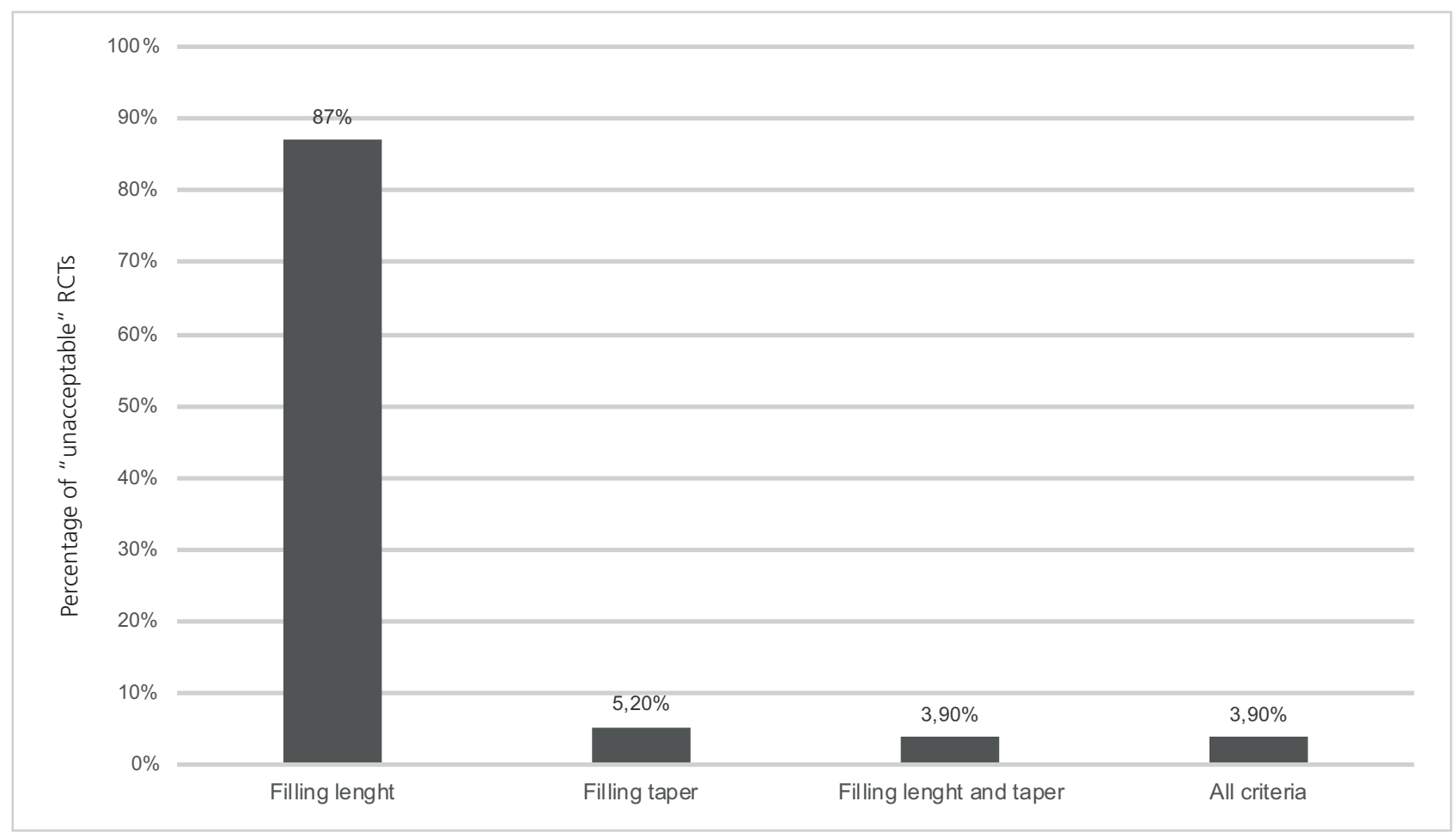

Figure 1. Distribution of unsatisfactory endodontic treated teeth $(n=77)$ according to filling homogeneity, filling level, and shape after obturation - Florianópolis/ SC, 2018. 
( $n=67)$ were underfilled canals and 8.2\% ( $n=6)$ overfilled. Furthermore, six students performed RCT with more than one quality criteria classified as unsatisfactory (figure 1). There were not found direct radiographic evidence of procedural errors (e.g., perforations, transportations, ledges, and file separations) in this sample.

\section{DISCUSSION}

In this study sample, the overall quality of RCT was of $71.9 \%$, which is higher than some studies reported $[6,16-18]$ and lower than others $[10,19]$. A systematic review recently published concluded that the frequency of acceptable RCTs performed by undergraduate students varies according to teeth groups [15]. In our study, the technical quality for anterior teeth and premolars was higher than the estimated rates for these treatments performed by undergraduate students [15]. However, canines and premolars presented a lower final quality than incisors, which was related mainly to root canal filling length.

Generally, students of the dentistry school of UFSC are not allowed to perform RCTs in molars, due to high difficulties that this group of teeth can present. This fact may have influenced the frequency of acceptable RCTs found in this sample since some studies reported a decrease in quality of the RCT in posterior teeth $[8,20,21]$. On the other hand, there are reports of a similar overall quality of RCT performed by undergraduate students in anterior and posterior teeth [12]. Some authors suggest that dental students should treat cases with minimal difficulty at the beginning of clinical practice, and treat a more considerable amount of teeth during the endodontic clinic [20].

Several studies in literature compare the quality of RCT performed by hand and rotatory/reciprocate instrumentation techniques [22, 23]. In our sample, all cases were performed by hand instrumentation. Usually automatized systems for endodontic instrumentation presentabetterqualityassessment than hand instrumentation, especially when inexperienced operators perform RCT [21]. The implementation of new technologies in the endodontic education in UFSC dental school may help the achievement of even better quality rates of RCTs and, therefore, training more skilled and prepared students.
The main issue regarding the quality of RCT performed by undergraduate students in our sample was the length of the filling material in relation with the radiographic apex, which in the majority of unsatisfactory cases was underfilled. We considered as satisfactory when the filling material was shorter than $2 \mathrm{~mm}$ from the apex, which is the most acceptable in literature. Other studies report failures in root canal filling length as the central issue regarding RCT performed by undergraduate students [12]. Failure in the root canal filling length jeopardizes treatment outcome, influencing the re-intervention rates $[2,24]$.

Another factor that may have influenced the overall quality rate found in this study is the professor/ students rates, which was 1:10 in this sample. This rate is similar to USA and Scandinavian dental schools (1:9) [25], and lower than British (1:13) [13], German (1:16) [26] and Saudi (1:12) [27]. At the endodontic clinics of UFSC, students treat patients in pairs, therefore, the professor/ student rate decrease for 1:5, which is lower than reported in other studies $[17,25]$. Considering that students in the dental school are acquiring knowledge for further professional activities, guidance in clinical procedures seems essential for developing appropriate skills and formations of more qualified professionals. In some occasions, postgraduate students supervise undergraduate students in endodontic procedures [28]. In our study, all supervision was performed by Ph.D. professors, which may have influenced the acceptable RCT's quality rates.

According to European and Americans guidelines, dental undergraduate students need to be able to perform RCT in single-rooted teeth and teeth presenting multiple canals upon graduation. Several studies reported a decrease in RCT quality from teeth with single to teeth with multiple canals $[8,20,21]$. In this sample, the quality of RCT in teeth with one or two canals was similar. Moreover, no treatment was performed in molars, which may have influenced these results, since posterior teeth present a high difficulty in RCT for undergraduate students to perform.

Root canal curvature was not frequent in our sample, only $7 \%$ of the teeth presented curvature. In which, the only criteria grade as unacceptable was underfilling that was present in approximately $23 \%$. Some authors described that with the increase in difficulty there is also a decrease in the quality of RCT performed by undergraduate students $[3,16]$. Root canal curvature may lead to challenges in instrumentation of all root 
canal length, which may lead to further complications in $\mathrm{RCT}$, even for experienced professionals [4]. Therefore, it is essential that professors in endodontic clinics supervise closely RCT performed in curved teeth, to avoid errors and, consequently, demotivation of the student.

Even though the acceptable treatment quality rate was high in this sample, it is essential to have in mind that not all procedure errors are detectable by radiographic examination. For example, extrusion of sodium hypochlorite beyond the apex can cause severe clinical sequelae and deserve particular attention [29]. Furthermore, as important as evaluating RCT's quality, assessing treatment outcome may provide a better understanding of the effectiveness of undergraduate endodontic clinic teachings procedures [30].

\section{CONCLUSION}

The most frequent error present was in the length of the filling material in relation to the radiographic apex. Incisors had better quality assessment rates than canines and premolars. The high-quality rates found in this sample may be linked to the professor/student rates.

\section{Collaborators}

DM RIBEIRO participated in the study concepts and design, data acquisition, quality control, data analysis, manuscript editing and review. MD HECKEL participated in data acquisition, quality control, data analysis, manuscript editing and review. FW MELLO collaborated with data analysis, statistical analysis, manuscript preparation, editing and review. MCS FELIPPE participated in study concepts and design, quality control, data analysis, manuscript editing and review and WT FILIPPE collaborated with study concepts and design, quality control, data analysis, manuscript editing, and review".

\section{Acknowledgments}

This study was financed in part by the Coordenação de Aperfeiçoamento de Pessoal de Nível Superior - Brasil (CAPES) - Finance Code 001. Fernanda Weber Mello [grant number 88887.200724/2018-00] is supported by the Fundação de Amparo à Pesquisa e Invovação do Estado de Santa Catarina (FAPESC). The authors would like to thank Helison Bertoli Alves Dias for his help with the statistical analysis.

\section{REFERENCES}

1. European Society of Endodontology. Quality guidelines for endodontic treatment: consensus report of the European Society of Endodontology. Int Endod J. 2006;39(12):921-30.

2. Ng YL, Mann V, Rahbaran S, Lewsey J, Gulabivala K. Outcome of primary root canal treatment: systematic review of the literature -- Part 2. Influence of clinical factors. Int Endod J. 2008;41(1):6-31. http://dx.doi.org/10.1111/j.1365-2591.2007. 01323.x

3. Barrieshi-Nusair KM, Al-Omari MA, Al-Hiyasat AS. Radiographic technical quality of root canal treatment performed by dental students at the Dental Teaching Center in Jordan. J Dent. 2004;32(4):301-7. http://dx.doi. org/10.1016/j.jdent.2004.01.002

4. Eleftheriadis GI, Lambrianidis TP. Technical quality of root canal treatment and detection of iatrogenic errors in an undergraduate dental clinic. Int Endod J. 2005;38(10):72534. http://dx.doi.org/10.1111/j.1365-2591.2005.01008.x

5. Agrafioti A, Giannakoulas DG, Kournetas N, Grigoriou S, Kontakiotis EG. Different Patterns of Restoration Provision Between Initial Endodontic Treatment and Retreatment: A Retrospective Clinical Study. Int J Prothodont. 2017;30(4):354-6.

6. Ilguy D, Ilguy M, Fisekcioglu E, Ersan N, Tanalp J, Dolekoglu S. Assessment of root canal treatment outcomes performed by Turkish dental students: results after two years. J Dent Educ. 2013;77(4):502-9.

7. Estrela C, Holland R, Estrela CR, Alencar AH, Sousa-Neto $M D$, Pecora JD. Characterization of successful root canal treatment. Braz Dent J. 2014;25(1):3-11. http://dx.doi.org/10. 1590/0103-6440201302356

8. Pirani C, Chersoni S, Montebugnoli L, Prati C. Long-term outcome of non-surgical root canal treatment: a retrospective analysis. Odontology. 2015;103(2):185-93. http://dx.doi. org/10.1007/s10266-014-0159-0

9. Lynch CD, Burke FM. Quality of root canal fillings performed by undergraduate dental students on single-rooted teeth. Eur J Dent Educ. 2006;10(2):67-72. http://dx.doi.org/10.1111/j.16 00-0579.2006.00397.x

10. Unal GC, Kececi AD, Kaya BU, Tac AG. Quality of root canal fillings performed by undergraduate dental students. Eur J Dent. 2011;5(3):324-30.

11. Burke FM, Lynch CD, Ni Riordain R, Hannigan A. Technical quality of root canal fillings performed in a dental school and the associated retention of root-filled teeth: a clinical followup study over a 5-year period. J Oral Rehabil. 2009;36(7):50815. http://dx.doi.org/10.1111/j.1365-2842.2009.01966.x

12. Fong W, Heidarifar O, Killough S, Lappin MJ, El Karim IA. An audit on technical quality of root fillings performed by undergraduate students. Int Endod J. 2017;51 Suppl 3:e197-e203. http://dx.doi.org/10.1111/iej.12803

13. Hayes SJ, Gibson M, Hammond M, Bryant ST, Dummer PM. An audit of root canal treatment performed by undergraduate students. Int Endod J. 2001;34(7):501-5. https://doi.org/10. 1046/j.1365-2591.2001.00421.x. 
14. Plasschaert AJ, Holbrook WP, Delap E, Martinez C, Walmsley $A D$. Profile and competences for the European dentist. Eur J Dent Educ. 2005;9(3):98-107. http://dx.doi.org/10.1111 / j.1600-0579.2005.00369.x

15. Ribeiro DM, Reus JC, Felippe WT, Pacheco-Pereira C, Dutra KL, Santos JN, et al. Technical quality of root canal treatment performed by undergraduate students using hand instrumentation: a meta-analysis. Int Endod J. 2018;51(3):269-83. http://dx.doi.org/10.1111/iej.12853

16. AlRahabi MK. Evaluation of complications of root canal treatment performed by undergraduate dental students. Libyan J Med. 2017;12(1):1345582. http://dx.doi.org/10.108 0/19932820.2017.1345582

17. Eskandarloo A, Karkehabadi H, Hoseini Hashemi SZ, Ahmadi M, Hendi SS. Radiographic quality of root canal obturation performed by fifth year students of hamadan dental school. Iran Endod J. 2017;12(2):236-41.

18. Khabbaz MG, Protogerou E, Douka E. Radiographic quality of root fillings performed by undergraduate students. Int Endod J. 2010;43(6):499-508. http://dx.doi.org/10.1111/j.1365-25 91.2010.01706.x

19. Vukadinov T, Blazic L, Kantardzic I, Lainovic T. Technical quality of root fillings performed by undergraduate students: a radiographic study. ScientificWorldJournal. 2014;2014:751274. http://dx.doi.org/10.1155/2014/751274

20. Alsulaimani RS, Al-Manei KK, S AA, AlAqeely RS, S AMA-S, E MA-M. Effects of Clinical Training and Case Difficulty on the Radiographic Quality of Root Canal Fillings Performed by Dental Students in Saudi Arabia. Iran Endod J. 2015;10(4):26873. http://dx.doi.org/10.7508/iej.2015.04.012

21. Roman-Richon S, Faus-Matoses $V$, Alegre-Domingo $T$, Faus-Llacer VJ. Radiographic technical quality of root canal treatment performed ex vivo by dental students at Valencia University Medical and Dental School, Spain. Med Oral Patol Oral Cir Bucal. 2014;19(1):e93-7.

22. Arya A, Bali D, Grewal MS. Histological analysis of cleaning efficacy of hand and rotary instruments in the apical third of the root canal: A comparative study. J Conserv Dent. 2011;14(3):237-40. http://dx.doi.org/10.4103/0972-0707.85797

23. Sipert CR, Hussne RP, Nishiyama CK. Comparison of the cleaning efficacy of the FKG race system and hand instrument in molar root canal. J Appl Oral Sci. 2006;14(1):6-9. http://dx. doi.org/10.1590 / S1678-77572006000100002

24. Almohareb R, Ahlquist M, Englund GS. The association between root canal filling and treatment outcome. Swed Dent J. 2016;40(2):133-42.

25. Qualtrough AJ, Whitworth JM, Dummer PM. Preclinical endodontology: an international comparison. Int Endod J. 1999;32(5):406-14. https://doi.org/10.1046/j.1365-2591. 1999.00253.x

26. Sonntag D, Barwald R, Hulsmann M, Stachniss V. Pre-clinical endodontics: a survey amongst German dental schools. Int Endod J. 2008;41(10):863-8. http://dx.doi.org/10.1111/j.13 65-2591.2008.01438.x

27. Balto H, Al Khalifah S, Al Mugairin S, Al Deeb M, Al-Madi E. Technical quality of root fillings performed by undergraduate students in Saudi Arabia. Int Endod J. 2010;43(4):292-300. http://dx.doi.org/10.1111/j.1365-2591.2009.01679.x

28. Moradi S, Gharechahi M. Quality of root canal obturation performed by senior undergraduate dental students. Iran Endod J. 2014;9(1):66-70.

29. Guivarc'h M, Ordioni U, Ahmed HM, Cohen S, Catherine JH, Bukiet F. Sodium Hypochlorite Accident: A Systematic Review. J Endod. 2017;43(1):16-24. http://dx.doi.org/10.1016/j.joen. 2016.09.023

30. Eriksen HM, Kirkevang L-L, Petersson H. Endodontic epidemiology and treatment outcome: general considerations. Endod Topics. 2002;2:1-9. https://doi.org/10.1034/j.1601-1546.2002. 20101.x

Received on: 5/11/2018

Final version resubmitted on: 10/12/2018

Approved on: 1/2/2019 